\title{
ANTIFEEDANT, GROWTH INHIBTORY AND TOXICITY EFFECTS OF CHLORANTRANILIPROLE, THIAMETHOXAM AND NOVALURON AGAINST THE COTTON LEAF WORM, SPODOPTERA LITTORALIS (BOISD.) (LEPIDOPTERA: NOCTUIDAE) IN COTTON FIELDS
}

\author{
AHMED A. BARRANIA \\ Plant Protection Research Institute, Etay El-baroud Agric. Res. Station. ARC, Egypt. \\ (Manuscript received 19 December 2012)
}

\begin{abstract}
Antifeedant, growth inhibtory and toxicity effects of chlorantraniliprole, thiamethoxam and novaluron formulations at $1,1 / 2$ and $1 / 4$ field recommended rates were tested against the cotton leafworm S. littoralis, during the cotton seasons of 2011 and 2012. Results showed that, feeding the $4^{\text {th }}$ instar larvae on treated cotton leaves at different rates decreased the food consumption. Morever, chlorantraniliprole seemes to be the most powerfull tested compounds. Feeding detrrence index for chlorantraniliprole, thiamethoxam and novaluron against $4^{\text {th }}$ instar Spodoptera larvae were $92.5,51.4$ and $71.9 \%$, respectively after one day expoure, at low rats ( $1 / 4$ field rate) during 2011 cotton season. While, Feeding detrrence index were $92.0,78.7$ and $76.9 \%$, respectively during 2012 cotton season.

The relative growth rate of $4^{\text {th }}$ instar Spodoptera larvae fed on cotton leaves treated with chlorantraniliprole, thiamethoxam and novaluron at $1,1 / 2$ and $1 / 4$ field rates was decreased. Toxicity of chlorantraniliprole, thiamethoxam and novaluron formulations was recorded clearly after two days expoure. After three days expoure, chlorantraniliprole gives $97.5,95.5$ and 95.0 percent mortality at 1 , $1 / 2$ and $1 / 4$ field rates, respectively against $4^{\text {th }}$ instar Spodoptera larvae during 2011 cotton season. Thiamethoxam gives 77.5, 67.5 and 60.0 percent mortality at $1,1 / 2$ and $1 / 4$ field rates, respectively, while novaluron gives $62.5,70.0$ and 60.0 percent mortality, respectively. During 2012 cotton season, chlorantraniliprole gives $95.0,95.0$ and 92.5 percent mortality at $1,1 / 2$ and $1 / 4$ field rates, respectively, while thiamethoxam gives $90.0,95.0$ and 87.5 percent mortality, respectively. Novaluron gave 97.5 percent mortality for all field rates.
\end{abstract}

\section{INTRODUCTION}

Cotton leafworm Spodoptera littoralis (Boisd) (family: Noctuidae) is a serious lepidopteran pest of cotton through its different growth stages. In Egypt, larvae are heavily attacking vegetables and field crops including cotton causing severe damage and consequently reduction in the obtained yield(Pluschkell et. al., 1998 and Korrat et. al., 2012). Loss of about $50 \%$ of the cotton leaf area during the $1^{\text {st }}, 2^{\text {nd }}$ and $3^{\text {rd }}$ generations of Spodoptera larvae reduced yield by 50, 65 and $40 \%$ respectively (El- 
Sherif et. al., 1991). Natural defoliations by Spodoptera larvae (20-70\%) can result in reductions in yield $\leqslant 50 \%$ (Russell et. al., 1993).

Chlorantraniliprole is a new anthranilic diamide insecticide, which effectively controls pest insects belonging to Lepidoptera, Coleoptera, Diptera and Hemispheres, and has been shown to be effective against insects that have developed resistance to older classes of chemistry. Anthranilic diamides selectively bind to ryanodine receptors in insect muscles resulting in an uncontrolled release of calcium from internal stores in the sarcoplasmic reticulum (Lahm et. al., 2005 and Cordova et. al. 2006), causing impaired regulation of muscle contraction leading to feeding cessation, lethargy, paralysis, and death of target organisms. Anthranilic diamides have very low vertebrate toxicity due to a $>500$-fold differential selectivity toward insect over mammalian ryanodine receptors (Cordova et. al. 2006).

Thiamethoxam is a broad spectrum neonicotenoid contact insecticide. The insecticidal activity of neonicotenoid is primarily attributed to their action on nicotinic acetylcholine receptors (nAChRs) (Karlin, 2002, Tomizawa and Casida, 2005). Neonicotenoid acute toxicity is ascribed primarily to their action as nicotinic agonists, acting on insect and mammal nAChRs (Tomizawa and Casida, 2003). On the other hand, several pieces of evidence in the literature show that neonicotenoid insecticides present a higher selectivity for the insect nAChRs than for the mammalian ones. Because of this selective activity, thiamethoxam has been evaluated as a seed treatment for several major field crops, including cotton (Arthur et. al. 2004).

Novaluron is a relatively new chitin synthesis inhibitor. It inhibits the chitin formation on larvae of various insects (Lepidoptera, Coleoptera, Homoptera and Diptera). Thus, it has a potent insecticidal activity against several important foliage feeding insect pests (Cutler et. al., 2005) and very low toxicity to mammals, birds and earthworms. By inhibiting chitin formation, novaluron selectively targets immature insect stages, causing abnormal endocuticular deposition abortive molting (Rachid et. al. 2009).

The purpose of this study was to determine the efficacy of chlorantraniliprole, thiamethoxam and novaluron as antifeedant, growth inhibtory and toxic agent against the cotton leafworm S. littoralis, during the cotton seasons of 2011 and 2012 at Etay Elbaroud Agricultural Research Station, El-Beheira Governorate. 


\section{MATERIALS AND METHODS}

\section{Tested compounds}

1. Coragen $20 \%$ SC (Chlorantraniliprole). It was provided by DU PONT DU NEMOURS Company.

2. Actara $25 \%$ WG (Thiamethoxam). It was provided by Syngenta Company.

3. Roxy $10 \%$ EC (Novaluron). It was provided by United Phosphorus Ltd.

\section{Field strain of Spodoptera littoralis}

Egg-masses of Spodoptera littoralis were collected from cotton fields at ElBeheira Governorate and directly transferred to the laboratory. After hatching the egg-masses were reared according to El-Defrawi et. al., (1964) and $4^{\text {th }}$ instar of Spodoptera larvae used for the experimental method.

\section{The semi-field trial}

Cotton experimental area was divided into 40 plots, each plot 1/100 feddan $\left(42 \mathrm{~m}^{2}\right)$. Randomized complete blocks design was used with four replicates for each treatment. A series of concentrations in water for chlorantraniliprole, thiamethoxam, novaluron and lufenron were used. Samples of treated leaves were randomly taken from each treatment to the laboratory where they were introduced to larvae. Fourth instar larvae of $S$. littoralis (newly moulted) with an average weight of $40-45 \mathrm{mg}$ were used. Four replicates of ten larvae each were used in each treatment, as well as, the control. In each replicate larvae were confined with treated leaves for 24 hours, after which they were transferred to clean glasses and provided regularly with fresh treated cotton leaves for four days. Dead larvae were discarded while the fresh weight of survivors and consumed serface area of cotton leaves discs $\left(530 \mathrm{~mm}^{2}\right)$ in each reaing glasses were recorded daily and related to the number of survivors in each experiment.

\section{Data analsys}

From test data, the following could be calculated: feeding deterrence index (FDI) $=[(C-T) /(C+T)] \times 100$, where $C$ and $T$ are the control and treated leaf consumed by the insect (Sadek, 2003).This index evaluates the potential of a substance to induce the cessation on feeding when tasted by an insect, and whether continues feeding in an alternative source of food.

The relative growth rate (RGR) was calculated according to (Farrar et. al., 1989): $R G R=[\Delta B / B I] \times T$, where $\Delta B$ change in insect body weight $(\mathrm{mg}), B I$ initial larval weight and $T=$ feeding period (days).

Percentage mortalities were corrected and calculated according to Abbott's formula, (Abbott, 1925). 


\section{RESULTS AND DISCUSSION}

Antifeedant, growth inhibtory and toxicity, effects of chlorantraniliprole, thiamethoxam and novaluron formulations at $1,1 / 2$ and $1 / 4$ field recommended rates were tested against the cotton leafworm $S$. littoralis, during the cotton seasons of 2011 and 2012. Data in table (1) summarized feeding detrrence index for chlorantraniliprole, thiamethoxam and novaluron formulations at $1,1 / 2 \& 1 / 4$ field recommended rates were tested against the cotton leafworm $S$. littoralis. The data indicated that, when $4^{\text {th }}$ instar Spodoptera larvae fed on cotton leaves treated with different rates, cotton leaves consumption for Spodoptera larvae is decreased. Morever, chlorantraniliprole seemes to be the most powerfull tested compounds against $4^{\text {th }}$ instar Spodoptera larvae. Feeding detrrence index for chlorantraniliprole, thiamethoxam and novaluron against $4^{\text {th }}$ instar Spodoptera larvae were 92.5, 51.4 and $71.9 \%$, respectively after one day expoure, at $1 / 4$ field rate during 2011 cotton season. While, Feeding detrrence index were 92.0, 78.7 and $76.9 \%$, respectively during 2012 cotton season.

Table. 1. Antifeedant activity of chlorantraniliprole, thiamethoxam and novaluron against 4th instar Spodoptera larvae at different exposure time during 2011 and 2012 coton seasons.

\begin{tabular}{|c|c|c|c|c|c|c|c|}
\hline \multirow{3}{*}{$\begin{array}{l}\text { Time } \\
\text { expposure }\end{array}$} & \multirow{3}{*}{$\begin{array}{c}\text { Doses } \\
\text { (Field rats) }\end{array}$} & \multicolumn{6}{|c|}{ Feeding detrrence index (FDI) } \\
\hline & & \multicolumn{3}{|c|}{2011} & \multicolumn{3}{|c|}{2012} \\
\hline & & Chlo & Thia & Nova & Chlo & Thia & Nova \\
\hline \multirow{3}{*}{1 day } & $1 \mathrm{f}$ & 99.3 & 55.3 & 60.2 & 95.8 & 90.1 & 79.0 \\
\hline & $1 / 2$ & 93.1 & 56.6 & 65.6 & 93.4 & 85.8 & 77.9 \\
\hline & $1 / 4$ & 92.5 & 51.4 & 71.9 & 92.0 & 78.7 & 76.9 \\
\hline \multirow{3}{*}{2 days } & $1 \mathrm{f}$ & 99.7 & 81.8 & 86.7 & 100.0 & 99.9 & 96.5 \\
\hline & $1 / 2$ & 99.7 & 75.3 & 78.7 & 100.0 & 99.9 & 94.1 \\
\hline & $1 / 4$ & 100.0 & 89.8 & 78.2 & 100.0 & 99.8 & 96.9 \\
\hline \multirow{3}{*}{3 days } & $1 \mathrm{f}$ & 100.0 & 94.6 & 96.4 & 100.0 & 100.0 & 100.0 \\
\hline & $1 / 2$ & 100.0 & 91.0 & 95.7 & 100.0 & 100.0 & 99.1 \\
\hline & $1 / 4$ & 100.0 & 96.7 & 98.3 & 100.0 & 99.9 & 100.0 \\
\hline
\end{tabular}

$\mathrm{FDI}=[(\mathrm{C}-\mathrm{T}) /(\mathrm{C}+\mathrm{T})] \times 100$, where $\mathrm{C}$ and $\mathrm{T}$ are the control and treated leaf consumed by the insect (Sadek, 2003),

Chlo $=$ Chlorantraniliprole, Thia $=$ Thiamethoxam, Nova $=$ Novaluron 
Table. 2. Growth inhibtory effect of chlorantraniliprole, thiamethoxam and novaluron against 4th instar Spodoptera larvae at 2011 and 2012 coton seasons.

\begin{tabular}{|c|c|c|c|c|c|c|c|c|c|c|c|}
\hline \multirow{3}{*}{ 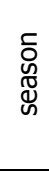 } & \multirow{3}{*}{$\begin{array}{l}\text { Feeding } \\
\text { period }\end{array}$} & \multicolumn{10}{|c|}{ The relative growth rate (RGR) } \\
\hline & & \multirow{2}{*}{ Control } & \multicolumn{3}{|c|}{ Chlorantraniliprole } & \multicolumn{3}{|c|}{ Thiamethoxam } & \multicolumn{3}{|c|}{ Novaluron } \\
\hline & & & $1 / 4$ & $1 / 2$ & 1 & $1 / 4$ & $1 / 2$ & 1 & $1 / 4$ & $1 / 2$ & 1 \\
\hline \multirow{3}{*}{ 귱 } & 1 day & 0.63 & 0.03 & 0.00 & 0.00 & 0.05 & 0.05 & 0.00 & 0.00 & 0.03 & 0.03 \\
\hline & 2 days & 5.00 & 0.00 & 0.00 & 0.00 & 0.45 & 0.15 & 0.10 & 0.10 & 0.10 & 0.10 \\
\hline & 3 days & 12.75 & -0.83 & -0.68 & -1.13 & 0.15 & 0.08 & -0.83 & -0.83 & -0.30 & -0.68 \\
\hline \multirow{3}{*}{ 궁 } & 1 day & 1.11 & 0.04 & 0.07 & 0.04 & 0.20 & 0.13 & 0.31 & 0.31 & 0.29 & 0.24 \\
\hline & 2 days & 6.44 & 0.00 & -0.09 & 0.06 & 0.22 & 0.90 & 0.53 & 0.53 & 0.53 & 0.36 \\
\hline & 3 days & 14.60 & -0.60 & -0.93 & 0.33 & -0.60 & -0.67 & 0.07 & 0.07 & 0.07 & 0.13 \\
\hline
\end{tabular}

$R G R=[\Delta B / B I] \times T$, where $\Delta B$ change in insect body weight $(\mathrm{mg}), B I$ initial larval weight, $T=$ feeding period (days) (Farrar et. al., 1989).

At the same conditions, the relative growth rate of $4^{\text {th }}$ instar Spodoptera larvae fed on cotton leaves treated with chlorantraniliprole, thiamethoxam and novaluron at $1,1 / 2$ and $1 / 4$ field rates were calculated (Table 2). The data indicated that, the majority of insecticides treatments decreased the relative growth rate of $4^{\text {th }}$ instar Spodoptera larvae.

General pattern was observed for the formulations, where the toxicity is increased with increasing the time elapsed after treatment. When cotton plants were sprayed with different field rates of chlorantraniliprole, thiamethoxam and novaluron formulations, toxicites were recorded clearly after two days expoure. Data in table (3) showed that, after three days expoure, chlorantraniliprole gives 97.5, 95.5 and 95.0 percent mortality at $1,1 / 2$ and $1 / 4$ field rates, respectively against $4^{\text {th }}$ instar Spodoptera larvae during 2011 cotton season. Thiamethoxam gives 77.5, 67.5 and 60.0 percent mortality at $1,1 / 2$ and $1 / 4$ field rates, respectively, while novaluron gives $62.5,70.0$ and 60.0 percent mortality, respectively. During 2012 cotton season, chlorantraniliprole gives $95.0,95.0$ and 92.5 percent mortality at $1,1 / 2$ and $1 / 4$ field rates, respectively, while thiamethoxam gives $90.0,95.0$ and 87.5 percent mortality, respectively. Novaluron gives 97.5 percent mortality for all field rates. 
Table. 3. Toxicity of chlorantraniliprole, thiamethoxam and novaluron against 4th instar of Spodoptera larvae after application of different insecticide doses during 2011 and 2012 coton seasons.

\begin{tabular}{|l|c|c|c|c|c|c|}
\hline \multirow{2}{*}{ Treatment (Field rats) } & \multicolumn{5}{|c|}{ \%Mortality after treatment } \\
\cline { 2 - 7 } & \multicolumn{2}{|c|}{2011} & \multicolumn{3}{c|}{2012} \\
\cline { 2 - 7 } & 1 day & 2 days & 3 days & 1 day & 2 days & 3 days \\
\hline Chlorantraniliprole & 20.0 & 92.5 & 97.5 & 22.5 & 60.0 & 95.0 \\
\hline Chlorantraniliprole1/2 & 17.5 & 90.0 & 95.5 & 27.5 & 50.0 & 95.0 \\
\hline Chlorantraniliprole1/4 & 22.5 & 85.0 & 95.0 & 20.0 & 52.5 & 92.5 \\
\hline Thiamethoxam & 17.5 & 65.0 & 77.5 & 20.0 & 50.0 & 90.0 \\
\hline Thiamethoxam1/2 & 12.5 & 57.5 & 67.5 & 12.5 & 57.5 & 95.0 \\
\hline Thiamethoxam1/4 & 2.5 & 50.0 & 60 & 20.0 & 40.0 & 87.5 \\
\hline Novaluron & 5.0 & 55.5 & 62.5 & 20.0 & 42.5 & 97.5 \\
\hline Novaluron1/2 & 12.5 & 57.5 & 70.0 & 20.0 & 62.5 & 97.5 \\
\hline Novaluron1/4 & 27.5 & 50.0 & 60.0 & 30.0 & 62.5 & 97.5 \\
\hline
\end{tabular}

In summary, this study has presented the novel observation that field doses and sublethal doses of chlorantraniliprole, thiamethoxam and novaluron formulations appears antifeedant, growth inhibtory and toxic effects against the cotton leafworm S. littoralis. These results were agreement with those obtained by Cutler et. al., (2005) and Jia et. al. (2011) they found that thiamethoxam, chlorantraniliprole and novaluron have a potent insecticidal activity against several important foliage feeding insect pests. Daniels et. al. 2009, they reported that, aphids feeding on wheat treated with thiamethoxam were reduced weight, body plan area and food consumption than aphids feeding on wheat treated with distilled water. Chlorantraniliprole causes feeding cessation, lethargy, muscle paralysis and ultimately death by activating the ryanodine receptor (Cao et. al., 2010 \& Cordova et. al. 2006 and Lahm et. al., 2005). Rachid et. al., (2009) showed that the highest concentrations of novaluron caused a dose-dependent growth inhibition of Paramecium population by reducing the chitin and cuticle of cells. 


\section{REFERENCES}

1. Abbott, W. S. 1925. A method for computing the effectiveness of an insecticide. J. Econ. Entomol. 18: 265-267.

2. Arthur, F. H., B. Yue and G. E. Wilde. 2004. Susceptibility of stored-product beetles on wheat and maize treated with thiamethoxam: effects of concentration, exposure interval, and temperature. J. Stored Products Res. 40: 527-546.

3. Cao, G., Q. Lu, L. Zhang, F. Guo, G. Liang, K. Wua, K. A.G. Wyckhuys and Y. Guo. 2010. Toxicity of chlorantraniliprole to Cry1Ac-susceptible and resistant strains of Helicoverpa armigera. Pestic. Biochem. Physiol. 98: 99-103.

4. Cordova, D., E. A. Benner, M. D. Sacher, J. J. Rauh, J. S. Sopa, G. P. Lahm, T. P. Selby, T. M. Stevenson, L. Flexner, S. Gutteridge, D. F. Rhoades, L. Wu, R. M. Smith and Y. Tao. 2006. Anthranilic diamides: a new class of insecticides with a novel mode of action, ryanodine receptor activation. Pestic. Biochem. Physiol. (84): 196-214.

5. Cutler, G. C., C D. Scott-Dupree, J. H. Tolman and C. R. Harris. 2005. Acute and sublethal toxicity of Novaluron, a novel chitin synthesis inhibitor, to Leptinotarsa decemlineata (Coleoptera: Chrysomelidae). J. Pest Management Sci. 61: 10601068.

6. Daniels, M., J. S. Bale, H. J. Newbury, R. J. Lind and J. Pritchard. 2009. A sublethal dose of thiamethoxam causes a reduction in xylem feeding by the bird cherry-oat aphid (Rhopalosiphum padi), which is associated with dehydration and reduced performance. J. Insect Physiol. (55): 758-765.

7. El-Defrawi, M. E., A. Toppozada, N. Mansour and M. Zeid. 1964. Toxicological studies on the Egyptian cotton leafworm, Prodenia litura. I. Susceptibility of different larval instar of Prodenia to insecticides. J. Econ. Entomol. 57 (4): 591593.

8. El-Sherif, S. I., I. S. Hawary and I. I. Mesbah. 1991. Economic threshold of infestation with the cotton leafworm, Spodoptera littoralis (Boisd.)(Lepidoptera: Noctuidae) in cotton fields in ARE. 3-Economic injury levels during the different generations. Arab J. Plant Protection. 9 (2): 116-123.

9. Farrar, R.: J. Barbour and G. Kennedy. 1989. Quantifying food consumption and growth in insects. Ann. Entomol. Soc. Am. (82): 593-598.

10. Lahm, G. P, T. P. Selby, J. H. Freudenberger, T. M. Stevenson, B. J. Myers, G. Seburyamo, B. K. Smith, L. Flexner, C. E. Clark and D. Cordova. 2005. Insecticidal anthranilic diamides: a new class of potent ryanodine receptor activators. Bioorgnic Medic. Chem. Lett. 15: 4898-4906. 
11. Jia, H., W.U. Shun-fan and Y. E. Gong-yin. 2011. Evaluation of Lethal Effects of Chlorantraniliprole on Chilo suppressalis and Its Larval Parasitoid, Cotesia chilonis. Agric. Sci. China. 10: 1134-1138.

12. Karlin, A. 2002. Emerging structure of the nicotinic acetylcholine receptors. Nat. Rev. Neurosci. (3): 102-114.

13. Korrat, E. E. E., A. E. Abdelmonem, A. A. R. Helalia and H. M. S. Khalifa. 2012.Toxicological study of some conventional and nonconventional insecticides and their mixtures against cotton leaf worm, Spodoptera littoralis (Boisd.) (Lepidoptera: Noectudae). Ann. Agric. Sci. 57 (2): 145-152.

14. Pluschkell, U., A. R. Horowitz, P. G. Weintraub and I. Ishaaya. 1998. DPX-MP062a potent compound for controlling the Egyptian cotton leafworm Spodoptera littoralis (Boisd.). Pestic. Sci. 54: 85-90.

15. Rachid R., F. Z. Saci, H. Berrebbah and M. R. Djebar. 2009. Toxic Effects of Combined Molecule from Novaluron and Diflubenzuron on Paramecium caudatum. American-Eurasian J. Toxicol. Sci. 1: 74-80.

16. Russell, D. A., S. M. Radwan, N. S. Irving, K. A. Jones and M. C. A. Downham. 1993. Experimental assessment of the impact of defoliation by Spodoptera littoralis on the growth and yield of Giza '75 cotton. Crop Protection. 12 (4): 303309.

17. Sadek, M. 2003. Antifeedant and toxic activity of Adhatoda vasica leaf extract against Spodoptera littoralis (Lepidoptera: Noctuidae). J. App. Entomol. (127): 396-404.

18. Tomizawa, M. and J. E. Casida. 2003. Selective toxicity of neonicotinoids attributable to specificity of insect and mammalian nicotinic receptors. Annu. Rev. Entomol. (48): 339-364.

19. Tomizawa, M. and J. E. Casida. 2005. Neonicotinoid insecticide toxicology mechanisms of selective action. Annu. Rev. Pharmacol. Toxicol. (45): 247-268. 


\section{تاثيرات منع التغذية، تثبيط النمو و السمية لكلورانترانيلييرول، الثياميثوكسام} والنوفاليورون ضد يرقات دودة ورق القطن فى حقول القطن

\section{أحمد عبدالحكيم برانيه}

\section{معهُ بحوث وقاية النباتات- محطة البحوث الزراعية بايتاى البارود- مركز البحوث الزراعية}

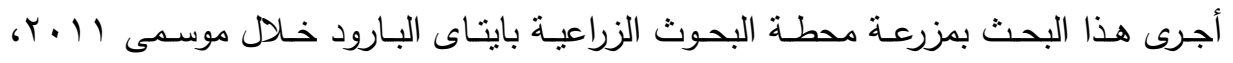

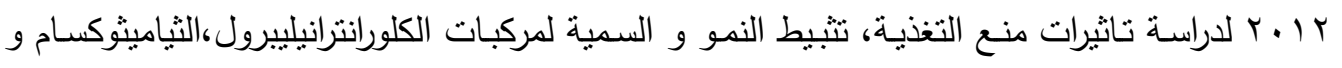
النوفاليورون ضد يرقات دودة ورق القطن (1/21/3 ، من المعدلات الحقلية على نباتات القطن معمليا

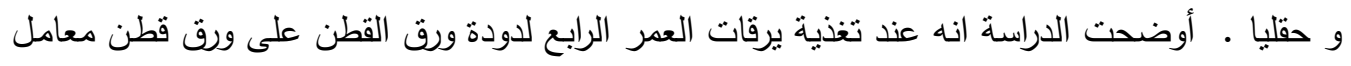
بتركيزات مختلفة، انخفض معدل الاستهلاك الغذائى و كان الكلورانترانيلييرول اكثر المركبات فاعلية.

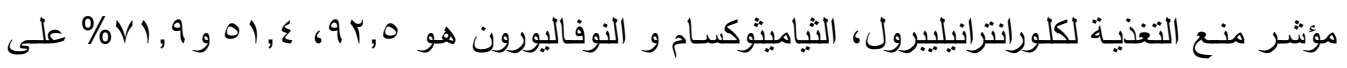

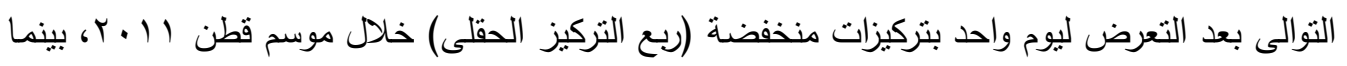

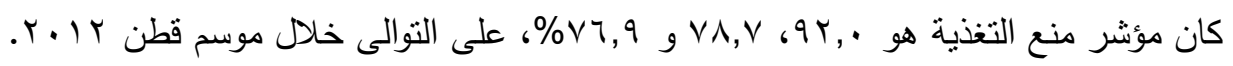

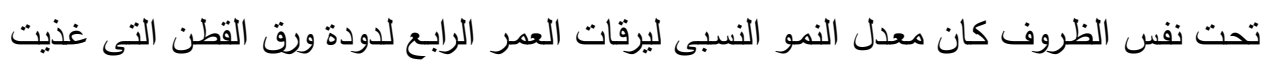

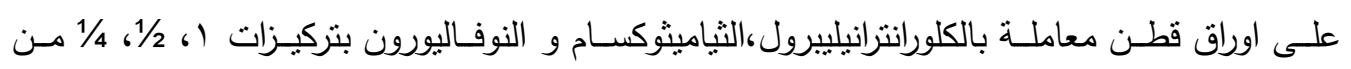
المعدلات الحقلية انخفض خلال الموسمين. :كانت سمية الكلورانترانيليبرول،الثياميثوكسام و النوفاليورون

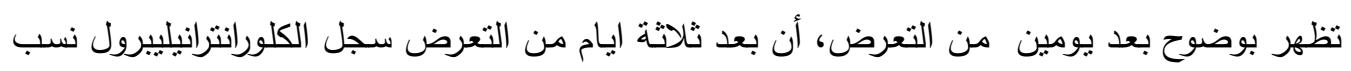

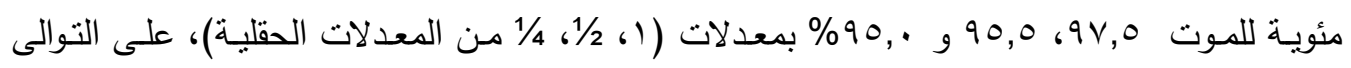

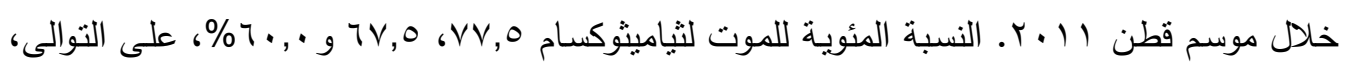

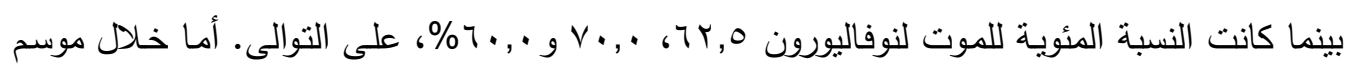

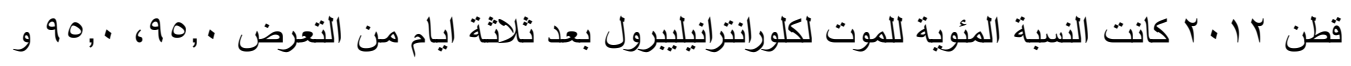

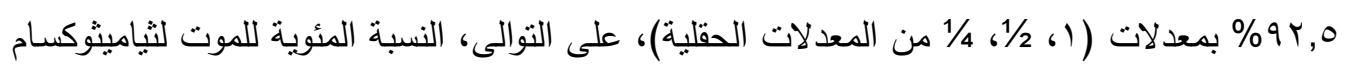

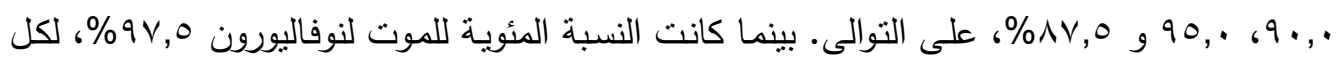

